\title{
PEOPLES' RIGHT TO A NATIONALITY AND THE ERADICATION OF STATELESSNESS IN AFRICA
}

\author{
DARREN EKEMA EWUMBUE MONONO*
}

The right to nationality, enshrined in art 15 of the Universal Declaration on Human Rights is absent in the 1981 African Charter on Human and Peoples' Rights, known as the Banjul Charter. On-going efforts by African institutions to address this gap, with a view to eradicating statelessness in the continent have, however, focused on the right to nationality as an individual right. This has undermined the spirit of the Banjul Charter, which consecrates peoples' rights as an African specificity. This article highlights the Banjul-led African human rights system and its specificities of human rights, particularly with regard to collective community and peoples' rights. Based on the recognition and communitarian theories, it examines different concepts related to collective rights and highlights the manifestation of peoples' rights in African case law. It then analyses the nexus between peoples' rights to nationality and statelessness in the continent. It concludes that the eradication of statelessness by 2024 in Africa cannot be effective unless the focus is on peoples' collective rights to nationality.

\section{TABLE OF CONTENTS}

I Introduction 33

II The Banjul Charter-Led African Human Rights System: Origins and Development

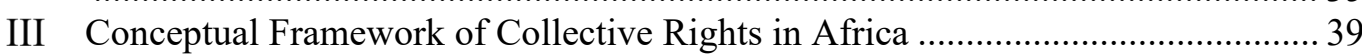

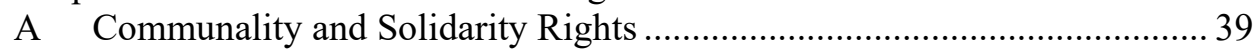

B Minority Rights and Indigenous Peoples' Rights ........................................ 40

C Community, Populations and Peoples' Rights ........................................... 41

D Peoples' Rights and Nationality Rights.................................................... 42

E Nationality Rights and Citizenship Rights .............................................. 43

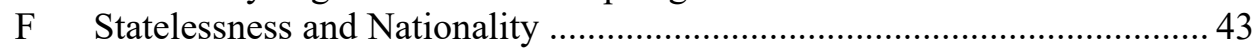

IV The Theoretical Foundation of Collective Nationality Rights...............................4 44

V Manifestation Of Collective Peoples' Rights in African Case Law ........................4 46

VI Peoples' Rights, Nationality Rights and the Prevention of Statelessness in Africa 48

A Manifestation of Individual and Collective Right to Nationality in African

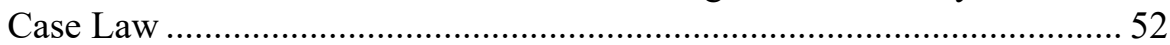

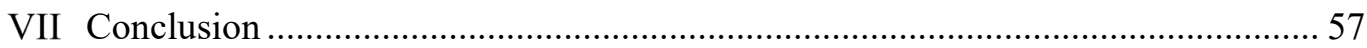

\section{INTRODUCTION}

The right to nationality is one of the most recognised fundamental rights in the modern state system. Even prior to the acknowledgement of nationality as a human right, the importance of nationality under international law was consecrated by the 1930 Convention on Certain Questions Relating to the Conflict in Nationality Law, which stated that '[e]very person should have a nationality and have one

* The author is a PhD Candidate in Governance and Regional Integration in the Pan African University, Yaounde, Cameroon. His research interests are on Peace Support Operations, Human Rights, Humanitarianism and Statelessness in Africa. He has had previous professional affiliations with the Office of the High Commissioner for Human Rights and the African Union. He is currently working with the United Nations High Commissioner for Refugees - Cameroon. 
nationality only'. ${ }^{1}$ The 1948 Universal Declaration on Human Rights ('UDHR'), in its art 15 acknowledged nationality as a human right, by stating that: 'Everyone has the right to a nationality' and 'No one shall be arbitrarily deprived of his nationality nor denied the right to change his nationality'. ${ }^{2}$ The right is further consecrated in other international human rights instruments such as the International Convenant on Civil and Political Rights ('ICCPR'), the 1989 Convention on the Rights of the Child and the American Convention on Human Rights. ${ }^{3}$

In Africa, the right to nationality is guaranteed and enjoyed by eight Afro-Arab countries who, collectively, are members of the Arab Maghreb Union ('AMU'), the African Union's Regional Economic Communities ('REC'), the Arab League, the Arab World, the Islamic World, and the Middle East and North Africa Region ('MENA') of international organisations such as the United Nations High Commissioner for Refugees ('UNHCR'). ${ }^{4}$ Here, the right is consecrated in art 29 of the revised 2004 Arab Charter on Human Rights, ${ }^{5}$ and art 7 of the Covenant of the Rights of the Child in Islam. ${ }^{6}$ Despite its recognition by the Afro-Arab and Islamic members, the right to nationality is not part of the Organisation of African Union ('OAU') and African Union ('AU') led African human rights system that governs some 48 countries of sub-Saharan Africa based on the 1981 African Charter on Human and Peoples' Rights ('Banjul Charter'). ${ }^{7}$

This article seeks to examine the on-going efforts by African human rights institutions, civil society organisations and the African Union in addressing the right to nationality in the continent with a view to eradicating statelessness. It describes the Banjul-led African human rights system, its origins and development. It presents a conceptual and theoretical framework to understand the various concepts and issues associated with collective rights in Africa, including their consecration by the case law of African human rights institutions. It highlights the particular characteristics of the questions of nationality and statelessness in the continent that have not been addressed by the existing regional and international instruments. It further analyses the nexus between peoples' rights as enshrined in the Banjul Charter and the right to a nationality. It concludes by demonstrating that the eradication of statelessness in Africa by 2024 as advocated

1 Convention on Certain Questions Relating to the Conflict of Nationality Laws, opened for signature 12 April 1930, 179 LNTS 89 (entered into force 1 July 1937).

2 Universal Declaration of Human Rights, GA Res 217A (III), UN GAOR, 3rd sess, 183rd plen mtg, UN Doc A/810 (10 December 1948).

3 International Covenant on Civil and Political Rights, opened for signature 19 December 1966, 999 UNTS 171 (entered into force 23 March 1976) art 24(3) ('ICCPR'); Convention on the Rights of the Child, opened for signature 20 November 1989, 1577 UNTS 3 (entered into force 2 September 1990) art 7; American Convention on Human Rights, opened for signature 22 November 1969, 1144 UNTS 123 (entered into force 18 July 1978) art 20.

4 The countries are Algeria, Egypt, Libya, Mauritania, Morocco, Tunisia, Sudan and Somalia.

5 See Arab Charter on Human Rights, opened for signature 22 May 2004, reprinted in 12 Intl Human Rights Rep 893 (entered into force 15 March 2008) art 29: (1) Every person has the right to a nationality, and no citizen shall be deprived of his nationality without a legally valid reason; (2) The state parties shall undertake, in accordance with their legislation, all appropriate measures to allow a child to acquire the nationality of his mother with regard to the interest of the child; (3) No one shall be denied the right to acquire another nationality in accordance with the applicable legal procedures of his country.

6 See Covenant on the Rights of the Child in Islam, opened for signature 28 June 2005, OIC/9IGGE/HRI/2004/Rep.Final, art 7.

7 African Charter on Human and Peoples' Rights, opened for signature 27 June 1981, 1520 UNTS 217 (entered into force 21 October 1986) arts 19-24 ('Banjul Charter'). 
by UNHCR-led global campaigns might not meet the target if it does not include collective and peoples' rights to nationality. ${ }^{8}$

The significance of the study cannot be overstated. Apart from individual human rights issues, the right to nationality and the prevention of statelessness in Africa could also be addressed as a specific African problem through the peoples' rights perspective of human rights, which is a unique African perspective. This will be an opportunity for the continent to provide its own solutions to this problem in accordance with the AU's policy of 'Africa Solutions to African Problems'. ${ }^{9}$ In fact, global stakeholders such as UNHCR and the Institute of Statelessness and Inclusion have carried out extensive research and published works on the subject. Unfortunately, global stakeholders have been unable to capture the aspect of collective peoples' rights regarding the right to nationality in a more rigorous and systematic manner, in order to shape it into a solution to the problem of eradicating statelessness.

Within the African perspective, therefore, the right to nationality, like the right to development provided for in art 22 of the Banjul Charter, is both an individual right and a peoples' right, which should be reflected in the new Protocol. ${ }^{10}$ The essence of this African perspective on human rights is not so much weighed on the concept of peoplehood, but rather on the collectivity and solidarity of rights on the continent. Finally, the study falls in line with Aspiration 6 of the African Union's Agenda 2063: An Africa whose Development is People-driven, Relying on the Potential of African People. ${ }^{11}$

\section{The BANJUl CHARTER-Led AfricAn Human Rights System: ORIGINS AND}

\section{DEVELOPMENT}

The history of human rights has often been categorised into three broad periods namely: pre-colonial, colonial and post-colonial periods. Scholars such as Ibrahima Fall have argued that although human rights were undocumented during the pre-colonial period, there is evidence of structured traditional societies in which basic human rights were respected. ${ }^{12}$ During the colonial period, Africans enjoyed limited political, economic, social and cultural rights. There were human

8 'Ending Statelessness', United Nations High Commissioner for Refugees (Web Page) $<$ https://www.unher.org/en-au/ending-statelessness.html $>$.

9 The notion of 'African Solutions' was first expressed in the 1993 'Declaration of the Assembly of Heads of State and Government on the Establishment within the OAU of a Mechanism for Conflict Prevention, Management and Resolution' (1994) 13(2-3) Refugee Survey Quarterly 174. It has gone on to be an expression used by African policy organs and scholars to mean the justifiable need for greater African responsibility, autonomy and the imperative to develop indigenous conflict prevention and management capacities: see Chrysantus Ayangafac, 'African Solutions to African Problems: In Search of the African Renaissance', Institute for Security Studies (Web Page, 9 July 2009) $<$ https://issafrica.org/amp/iss-today/african-solutions-to-african-problems-in-search-of-theafrican-renaissance $>$.

10 The African Union has, since 2015, been drafting a protocol to the African Charter on Human and Peoples Rights on the right to a nationality and the eradication of statelessness in Africa: African Union, African Commission on Human and Peoples' Rights, Draft Protocol to the African Charter on Human and Peoples' Rights on Certain Aspects of the Right to a Nationality and the Eradication of Statelessness in Africa (adopted September 2015) ('Draft Protocol to the African Charter').

11 See 'Agenda2063: Our Aspirations for the Africa We Want', African Union (Web Page) $<$ https://au.int/en/agenda2063/aspirations $>$.

12 See Ibrahima Fall, 'Des structures possibles à l'échelon régional africain pour la promotion des droits de l'homme' (1977) 22 Revue Sénégalaise de Droit 69, 69-79. 
rights abuses due to political repression, economic exploitation and socio-cultural assimilation. This time period was also marked by an increase in the documentation of human rights abuses, and the adoption of international human rights instruments such as the UDHR of 1948, the ICCPR of 1966 and the International Convenant on Economic, Social and Cultural Rights ('ICESCR') of 1966 at the global level and the 1950 European Convention on Human Rights and the 1969 American Convention on Human Rights at the regional level. ${ }^{13}$

The clamour for political rights, especially the right to self-determination within the frame of the ICCPR and ICESCR, was at the forefront of the struggle by African people for decolonisation and independence between 1960s and the 1980 s, which in some contexts involved liberation wars. ${ }^{14}$ There were also widespread political exclusions and discriminations within the African states resulting in armed conflicts, poor governance and human rights violations. During this period, the OAU recognised liberation movements as representing African people living under colonial and white-dominated regimes in Southern Africa. ${ }^{15}$

The people-centered perspective to human rights was largely influenced by the 1976 Universal Declaration of the Rights of Peoples ('Algiers Declaration'), which among other things, listed these peoples' rights in its 30 articles to include the rights to existence; to self determination; the right to a national and cultural identity; to minority rights, and the guarantees of these rights. ${ }^{16}$ These collective peoples' rights developed in the Algiers Declaration were therefore incorporated in the Banjul Charter in 1981. To address the diverse human rights issues in Africa, the continent has developed a distinct system based on the Banjul Charter, with specific regional institutions, mechanisms and values which are consistent with the universality principles of the international human rights system. The African human rights system highlights the fact that cultural relativism, local realities, and specificities are very important in the African human rights system. Carlson Anyangwe for instance posits that:

Regional human rights systems are critical in contemporary human rights development. They play an important complementary role in reinforcing international standards and machinery. They provide the means by which human rights concerns can be addressed within the particular social, historical, and political context of the region. Moreover, when it comes to human rights implementation, the universal human rights system relies heavily on regional human rights arrangements. ${ }^{17}$

According to Jean Désiré Ingange-wa-Ingange, the 'African Human Rights System' refers to 'the regional system of norms and institutions for enforcing

13 See Jean Désiré Ingange-wa-Ingange, 'The African Human Rights System: Challenges and Prospects' (LLD Thesis, University of South Africa 2010) 8-9; ICCPR (n 3); International Covenant on Economic, Social and Cultural Rights, opened for signature 16 December 1966, 993 UNTS 3 (entered into force 3 January 1976) art 1 ('ICESCR'); Convention for the Protection of Human Rights and Fundamental Freedoms, opened for signature 4 November 1950, 213 UNTS 221 (entered into force 3 September 1953); American Convention on Human Rights (n 3).

14 See ICCPR (n 3) art 1; ICESCR (n 13) art 1.

15 See Elizabeth Schmidt, Foreign Intervention in Africa: From the Cold War to the War on Terror (Cambridge University Press 2013) 103.

16 See Universal Declaration of the Rights of Peoples (4 July 1976) Preamble $<$ http://permanentpeoplestribunal.org/wp-content/uploads/2016/06/Carta-di-algeri-EN2.pdf $>$ ('Algiers Declaration').

17 See Carlson Anyangwe, 'Obligations of States to the African Charter on Human and Peoples Rights (1998) 10 African Journal of International and Comparative Law 625, 625. 
human and peoples' rights in Africa, or rather, a collectivity of mechanisms enforcing and protecting the rights of the African people. ${ }^{18}$ It is the normative framework and architecture that exists in the promotion and protection of human and peoples' rights on the continent both under the OAU and its successor AU. ${ }^{19}$

The instruments established under the OAU-led African human rights system include the OAU Convention on Specific Aspects Governing Refugees in Africa, the 1981 Banjul Charter, and the 1990 African Charter on the Rights and Welfare of the Child. Under the AU, new instruments were added, which include the 2003 Protocol to the African Charter on Human and Peoples' Rights on the Rights of Women in Africa ('Protocol on the Rights of Women in Africa'), the 2008 Protocol on the Statute of the African Court of Justice and Human Rights ('Protocol on the African Court of Justice'), the 2009 African Union Convention for the Protection and Assistance of Internally Displaced Persons in Africa ('Kampala Convention'), and the 2018 AU Protocol to the African Charter on Human and Peoples' Rights on the Rights of Persons with Disabilities in Africa ('Protocol on the Rights of Persons with Disabilities in Africa'). ${ }^{20}$ The mechanisms and institutions responsible for the enforcement of these continental human rights instruments include the African Commission on Human and Peoples Rights established in 1987, the African Committee of Experts on the Rights and the Welfare of the Child established in 2001, and the African Court on Human and Peoples' Rights ('the Court') established in 2004. It also includes the AU Secretariat for the Development of African International Law in Arusha, and the African Commission on International Law in Addis Ababa, Ethiopia.

Historically, one can trace the origin of the African human rights system to the 1979 OAU Summit in Monrovia when the Organisation took the lead in galvanising people of influence, emminent jurists, civil society organisations and the International Court of Justice to redress widespread human rights abuses across African states. Through its Assembly Resolution 115(XVI) of July 1979, the OAU created a Committee of Experts headed by Senegalese jurist, Keba M'baye, to draft a Human Rights Charter as well as its promotion and protection mechanisms. It is against this backdrop that the Banjul Charter was established as an indigenous African instrument to safeguard, protect and promote fundemental civil, political, economic, cultural and social rights at individual and collective levels. ${ }^{21}$

18 Ingange-wa-Ingange, 'The African Human Rights System: Challenges and Prospects' (n 13) 16.

19 Vincent O Nmehielle, 'Development of the African Human Rights System in the Last Decade' (2004) 11(3) Human Rights Brief 1.

20 Protocol to the African Charter on Human and Peoples' Rights on the Rights of Women in Africa, opened for signature 1 July 2003, OAU Doc CAB/LEG/66.6 (entered into force 25 November 2005) ('Protocol on the Rights of Women in Africa); Protocol on the Statute of the African Court of Justice and Human Rights, opened for signature on 1 July 2008 (not yet in force) ('Protocol on the African Court of Justice'); African Union Convention for the Protection and Assistance of Internally Displaced Persons in Africa, opened for signature 23 October 2009 (entered into force 6 December 2012) ('Kampala Convention'); Protocol to the African Charter on Human and Peoples' Rights on the Rights of Persons with Disabilities in Africa, opened for signature 29 January 2018 (not yet in force) ('Protocol on the Rights of Persons with Disabilities in Africa').

21 Assembly of the African Union, Resolution on the Preparation of a Preliminary Draft on An African Charter on Human and Peoples' Rights Providing, Inter Alia, for the Establishment of Bodies to Promote and Protect Human and Peoples' Rights, Doc No AGH/Res115(XVI), $16^{\text {th }}$ ord sess, 17-20 July 1979 called on the Secretary-General of the OAU to: 
The Banjul Charter was a human rights document built on political compromise at the peak of Cold War politics in the continent. It was therefore a compromise between the states advocating people-centred socialist systems with collective and solidarity rights on the one hand, and the liberal African countries advocating individual rights, on the other. ${ }^{22}$ It was also a compromise among the OAU political priorities at the time, based on principles such as the respect for sovereignty, non-interference in the internal affairs of member states, independence and self-determination, and the total liberation of Africa through the fight against colonialism and racist regimes. ${ }^{23}$

The Charter has the distinction of being the only international instrument to provide a detailed exposition of the rights of peoples, which is spelt out in arts 1924. Although it does not define the concept of peoples, it lists out the following rights and entilements to be enjoyed as peoples' rights, namely, the right of all peoples to equality (art 19); the right to existence and self-determination (art 20); the right to dispose freely of wealth and natural resources (art 21); the right to economic, social and cultural development (art 22); the right to national and international security (art 23), and the right to a general satisfactory environment $(\operatorname{art} 24) .{ }^{24}$

Some scholars have justified the rationale for the emergence of peoples' rights in the African human rights system. For instance, Maurice Glélé-Ahanhanzo holds that the concept of 'people' was the expression of the African struggle for independence, which was peoples' struggle. ${ }^{25}$ Pierre-Francois Gonidec argues that the Charter's affirmation of peoples' rights was a logical continuation of the OAU's support to national liberation movements, which represented the oppressed African people. ${ }^{26} \mathrm{He}$ makes the distinction between 'external self-determination' and 'internal self-determination' in which a people can enjoy within the contours of its national boundaries. He finally argues that 'Peoples' in the Banjul Charter refers to citizens of a state, those endowed with the political right to vote in accordance with art 13(1) of the Banjul Charter. Advocate of 'internal selfdetermination', UO Umozurike goes further to include the right of minorities to self-determination, with respect to state sovereignty and territorial integrity. ${ }^{27}$ Keba M'baye also argues that peoples' rights may be understood as a modern

(a) Draw the attention of Member States to certain international conventions whose ratification would held to strengthen Africa's struggle against certain scourge, especially apartheid and racial discrimination, trade imbalance and mercenaryism; (b) organise as soon as possible, in an African capital, a restricted meeting of highly qualified exerts to prepare a preliminary draft of a 'African Charter on Human and Peoples' Rights' providing, inter alia, for the establishment of bodies to promote and protect human and peoples' rights.

22 See generally Emmanuel Wonyu, 'Un support juridique pour la protection la démocratie en Afrique: La Charte Africaine des Droits de l'Homme et des Peuples' (1992) 8 Afrique 2000: Revue africaine de politique internationale 29 (copy on hand with the author).

23 ibid.

24 See Banjul Charter (n 7).

25 See generally Maurice Glélé-Ahanhanzo, 'Introduction à la Charte Africaine des Droits de l'Homme et des Peuples' in C A Colliard (ed) Droit et libertés à la fin du XXe siècle: influence des données économiques et technologiques: Études Offertes (Pedone 1984) 511 (copy on hand with the author).

26 See Pierre-François Gonidec, 'La Charte Africaine des Droits de l'Homme et des Peuples' (1983) 209-10 Le Mois en Afrique 22.

27 See U O Umozurike, 'The African Charter on Human and Peoples' Rights' (1983) 77(4) American Journal of International Law 902-12. 
answer to African political problems of neo-colonialism, foreign domination and the bloc policy. ${ }^{28}$

The Banjul Charter adopted by the OAU remained in force until the inception of the African Union in 2002. Under the OAU, a distinct African human right system was progressively put in place as Protocols to the Banjul Charter, which included the 1987 African Commission on Human and Peoples Rights, and the 1990 African Charter for the Rights and Welfare of the Child. Since then, the AUled African human rights system has been improved with the previously mentioned instruments based on the Banjul Charter: the 2003 Protocol on the Rights of Women in Africa, the 2004 Protocol on the African Court of Justice, the 2009 Kampala Convention and the 2018 AU Protocol on the Rights of Persons with Disabilities in Africa.

However, one of the greatest weaknesses of the Charter is the absence of the right to nationality, which could be enjoyed at individual, group and collective levels. There has been explicit structural discrimination, not only against individuals, but also against whole communities and ethnic groups who constitute people protected by arts 19-24 of the 1981 Banjul Charter. This gap has been conspicuous due to violations of individual rights to nationality for political reasons in the continent. ${ }^{29}$ More importantly, there have also been instances of collective denial, deprivation and discrimination against specific communities, groups and peoples in the continent, leading to mass statelessness. ${ }^{30}$

\section{CONCEPTUAl Framework OF COLLECTIVE RightS IN AFricA}

As a framework of analysis, the study will examine the various concepts and theories related to the right to nationality. It will also clarify and highlight the differences in the use of collective and group rights terms such as the 'communality' and 'solidarity rights', minority and indigenous rights, community and peoples' rights, peoples' nationality rights, and nationality and statelessness.

\section{A Communality and Solidarity Rights}

Ronald Garet, for instance, has developed a model to categorise and differentiate fundamental rights into three, based on 'personhood, communality and sociality'. ${ }^{31}$ According to him, personhood is the ground for individual rights whose objective is self-achievement. Communality, on the other hand, is the ground for rights of groups to maintain themselves and to pursue their distinctive course. ${ }^{32}$ Finally, sociality is the ground for the right of the existence of states and other artificial groupings created by humankind. ${ }^{33}$ The protection of collective

28 See Keba M'baye, 'Le droit au développement comme droit de l'homme' (1972) 5(2-3) Revue Des Droits de l'Homme 503.

29 There are many instances on these violations. One popular example is the deprivation of Kenneth Kuanda's nationality. On this case and the repercussions, see Georges NzongolaNtalaja, 'Citizenship, Political Violence and Democratization in Africa (2004) 10(4) Global Governance 403.

30 See, eg, Lisa Schlein, 'Mass Expulsion of Congolese from Angola Could Spark Humanitarian Crisis', VOA News (online, 16 October 2018) <https://www.voanews.com/africa/massexpulsion-congolese-angola-could-spark-humanitarian-crisis $>$.

31 Ronald Garet, 'Communality and Existence: The Right of Groups' (1983) 56 (5) Southern California Law Review 1001, 1016.

32 ibid 1002.

33 ibid 1008-9. 
rights, therefore, does not automatically flow out of the protection of individual rights. Central to the enjoyment of such rights is the perception by the group that they are distinct from other members of the national political community and the recognition by others of this specificity. The recognition of such communities by African Governments, including the putting in place of mechanisms to enable them to enjoy the right of nationality, is therefore very important.

\section{B Minority Rights and Indigenous Peoples' Rights}

Minority rights are the individual rights as applied to members of a racial, ethnic, religious, linguistic, or gender communities. The individual as well as collective dimensions of minority rights are embedded in art 3 of the 1992 United Nations Declaration on the Rights of Persons Belonging to National or Ethnic, Religious and Linguistic Minorities as well as in Francesco Capotorti's 1977 Study on the Rights of Persons Belonging to Ethnic and Linguistic Minorities. ${ }^{34}$ Athanasia Akermark, Will Kymlicka and Will Norman argue that there are four types of minorities: national minorities, immigrant minorities, religious minorities, and sui generis groups, which include stateless people with citizenship or rights. ${ }^{35}$

On the other hand, the rights of indigenous people came to light in 1989 when the Organization of American States elaborated a draft Declaration on the Rights of Indigenous People, which was approved in $1997 .{ }^{36}$ The rights of indigenous peoples are, however, encapsulated in the United Nations Declaration on the Rights of Indigenous Peoples ('UNDRIP'), which affirms that 'indigenous peoples possess collective rights, which are indispensable to their existence, wellbeing, and integral development as peoples. ${ }^{37}$ Article 33 of the UNDRIP further states that:

Indigenous peoples have the right to determine their own identity or membership in accordance with their customs and traditions. This does not impair the right of indigenous individuals to obtain citizenship of the States in which they live.

Indigenous peoples' rights also have a strong cultural bond to land. John Borrows calls such a bond 'landed citizenship.' 38 James Minahan's study highlights some 420 national groups and indigenous peoples in the world who may risk statelessness as they are not recognised by nation-states of the contemporary

34 Declaration on the Rights of Persons Belonging to National or Ethnic, Religious and Linguistic Minorities, GA Res 47/135, UN GAOR, 47th sess, 92nd plen mtg, UN Doc A/RES/47/135 (18 December 1992); Francesco Capotorti, Special Rapporteur, Study on the Rights of Persons Belonging to Ethnic, Religious and Linguistic Minorities, UN Doc E/CN.4/Sub.2/384/Add.1-7 (1979).

35 See Athanasia Akermark, Justification of Minority Protection in International Law (Kluwer 1997); Will Kymlicka and Will Norman (eds), Citizenship in Diverse Societies (Oxford University Press 2000).

36 See Organization of American States, Inter-American Commission on Human Rights, Annual Report, Doc No AG/RES 1022 (XIX-O/89), 9 ${ }^{\text {th }}$ plenary sess, 18 September 1989; Organization of American States, Proposed American Declaration on the Rights of Indigenous Peoples, Doc No AG/RES 1479 (XXVII-O/97), 7 th plenary sess, 5 June 1997.

37 Albert Kwokwo Barume, Land Rights of Indigenous Peoples in Africa: With Special Focus on Central, Eastern and Southern Africa (IWGIA Document No 128, March 2014) 176, quoting United Nations Declaration on the Rights of Indigenous Peoples, GA Res 61/295, UN GAOR, 61st sess, 107th plen mtg, Agenda Item 68, Supp No 49, UN Doc A/RES/61/29 (2 October 2007) 7.

38 John Borrows, 'Landed Citizenship: Narratives of Aboriginal Political Participation' in Kymlicka and Norman (eds), Citizenship in Diverse Societies (n 35) 327. 
international system. ${ }^{39}$ In Africa, the term covers 'native' African populations and those defined as such by UNDRIP and the Commission's Working Group on 'Indigenous Populations and Communities' such as the Bororo and Pygmies. ${ }^{40}$

The need for indigenous peoples to enjoy collective rights to nationality has been highlighted by researchers such as Willem van Genugten, Anna Meijknecht and Bas Rombouts, who argue that indigenous communities should be recognised as distinct people(s) as provided by international law. ${ }^{41}$ Cindy Holder and Jeff Conrtassel opine that many indigenous groups and communities emphasise the interdependence of individual and collective rights and recommend that a dual collective/individual rights to nationality be envisaged and enforced. ${ }^{42} \mathrm{P}$ Juviler has, however, differentiated between minority rights, which are individual rights, and indigenous rights, which are essentially collective rights. ${ }^{43}$

\section{Community, Populations and Peoples'Rights}

Communities are 'groups based upon unifying and spontaneous factors essentially beyond the control of members of the group.' ${ }^{4}$ They are entities that exist on cultural units and cannot be regarded as mere aggregate of individuals. They have a high sense of belonging, willingness to preserve solidarity between them, and share a common heritage and common destiny. On the other hand, a people is plurality of persons considered as a whole. This is the case with ethnic groups, nations, or the public of a polity. The 1989 UNESCO Committee of Experts further defined a people as a group of individual human beings who enjoy some or all of the following common features: (a) a common historical tradition; (b) racial or ethnic identity; (c) cultural homogeneity; (d) linguistic unity; (e) religious or ideological affinity; (f) territorial connection; and (g) a common economic life. $^{45}$

Ian Brownlie argues that a people should have a 'distinct character', which depends on factors such as race or nationality, culture, language, religion and group psychology. ${ }^{46}$ In Legal Resources Foundation $v$ Zambia, the African Commision on Human and Peoples' Rights extended the definition of people to 'an identifiable group of Zambian citizens by reason of their common ancestry,

39 James B Minahan. Encyclopedia of Stateless Nations: Ethnic and National Groups around the World ( $2^{\text {nd }}$ ed, Greenwood 2016) xi.

40 See Barume, Land Rights of Indigenous Peoples in Africa with Special Focus on Central, Eastern and Southern Africa (n 37) 47.

41 See Willem van Genugten, Anna Meijknecht and Bas Rombouts, 'Stateless Indigenous People(s): The Right to a Nationality, Including Their Own’ (2014) 19(1-2) Tilburg Law Review 98.

42 See Cindy L Holder and Jeff J Corntassel, 'Indigenous Peoples and Multicultural Citizenship: Bridging Collective and Individual Right' (2002) 24(1) Human Rights Quarterly 126, 12829.

43 Peter Juviler, 'Are Collective Rights Anti-Human? Theories on Self-Determination and Practice in Soviet Successor States' (1993) 11(3) Netherlands Quarterly of Human Rights 267.

44 See Definition and Classification of Minorities: Memorandum Submitted by the SecretaryGeneral, UN ESCOR, UN Doc E/CN/4/Sub.2/85 (27 December 1949) 5 [18].

45 See United Nations Educational, Scientific and Cultural Organisation, International Meeting of Experts on Further Study of the Concept of the Rights of Peoples Final Report and Recommendations, UN Doc SHS-89/CONF602/7 (22 Feb 1990) 7-8.

46 Ian Brownlie, 'The Rights of Peoples in Modern International Law' (1985) 9(2) Bulletin of the Australian Society of Legal Philosophy 104, 107-8. 
ethnic origin, language and cultural habits'. ${ }^{47}$ 'Community' rights are, therefore, a set of powers that give an individual greater participation in the management of the society. Fatash Ouguergouz contends that, as part of its rights to economic development, peoples' rights mean those of 'populations' within the state. $\mathrm{He}$ argues that the concept of 'populations' in French is closer to that of 'communities' in the English language. ${ }^{48}$ In fact, the terms 'populations' and 'communities' are now increasingly used interchangeably in African human rights circles such as in the 'Working Group on Indigenous Populations/Communities in Africa' of the Commission, created in $2000{ }^{49}$

The term 'community' might be increasingly preferred over 'peoples' for three main reasons. Firstly, it implies the idea of a cultural bond, living together, sharing common values and being willing to preserve a certain way of life. Secondly, 'community' is less politically charged than 'peoples'. It could be appropriate for building confidence between indigenous communities and their states since most African indigenous communities do not claim statehood, but autonomy, selfgovernance, and control over their lands and resources. Thirdly, the term 'community' is most likely to include any aggregate of individuals, similar to the concepts of 'minorities' and 'groups'.

\section{Peoples'Rights and Nationality Rights}

According to James Minahan, a nation is 'a body of people, associated with a particular territory, that is sufficiently conscious of its unity to seek or possess a government particularly its own' ${ }^{50}$ Paul James also holds that a nation is a stable community of people formed on the basis of a common language, territory, history, ethnicity, or physiological make up manifested in a common culture. ${ }^{51}$ From these definitions, it is clear that people are at the center of a nation. The rights of a people are therefore largely the rights of a nation. Ethnic nationalities also describe a people who share a common identity, language, culture, lineage, history, and so on. In his study on the right to self-determination in 1981, the UN Special Rapporteur on Prevention of Discrimination and Protection of Minorities, Aureliu Cristescu, stated that 'peoples', 'nations' and 'States' are holders on the right to self-determination because "the term "peoples" applies not only to States, but also to other entities'. ${ }^{52}$

'Nationality' is often considered to be the legal identification of a person in international law recognising a person as a subject of a recognised sovereign state; in order to make sense of the concept of nationality, it must be discussed with the

47 See Ingange-wa-Ingange, 'The African Human Rights System: Challenges and Prospects' (n 13) 223; Legal Resources Foundation v Zambia (African Commission on Human and Peoples' Rights, Comm 211/98, 29 ${ }^{\text {th }}$ ord sess, 7 May 2001).

48 See Fatsah Ouguergouz (ed), La Charte africaine des droits de l'homme et des peuples: Une approche juridique des droits de l'homme entre tradition et modernité (Genève: Graduate Institute Publications 1993) ch 5.

49 Indigenous Peoples in Africa: The Forgotten Peoples? The African Commission's Work on Indigenous Peoples in Africa (Report, African Commission on Human and Peoples' Rights and IWGIA 2006).

50 Webster's Unabridged Dictionary (online at 28 April 2021) 'nation', quoted in Minahan, Encyclopedia of Stateless Nations: Ethnic and National Groups around the World (n 39) xii.

51 See generally Paul James, Nation Formation: Towards a Theory of Abstract Community (Sage Publications 1996).

52 Cristescu Aureliu, Special Rapporteur, The Right to Self-determination: Historical and Current Development on the Basis of United Nations Instruments, UN Doc E/CN4/Sub2/404/Rev.1 (1981) 39. 
consubstantial concept of the state, this means, the existence of a nationality presupposes the existence of a sovereign state. ${ }^{53}$ Here, international law and legal theory are unanimous, since the former defines nationality as the 'legal bond between a person and a State', while the latter analyses it either as 'the fact that an individual legally belongs to the population making up a State'. ${ }^{4}$ The right to nationality is the right to acquire, change and retain a nationality. ${ }^{55}$ The right is now exercised as individual rights, but could equally be exercised by groups, communities and people recognised by a state, which confers the right to nationality.

\section{E Nationality Rights and Citizenship Rights}

Nationality differs technically and legally from citizenship, which is a sociopolitical relationship between a person and a country. Citizenship focuses on the internal political life of a state, while nationality is a matter of international law. It is the state of being vested with the rights, privileges and duties on an individual viewed as a member of a society. Citizenship involves the condition of exercising political, civil and social rights. A person can have the nationality of a state without having a sense of belonging that accompanies citizenship. Not all people with the nationality of a particular state are full citizens as some do not have the rights to vote. In mostly federal states, the constituent federated states might confer a type of 'regional citizenship' for their natives with regard to political, economic and social rights and services, to the exclusion of other nationals of the federal state. For example, the State of Israel's Supreme Court decision of October 2013 differentiates between the 'Israeli citizenship' for all nationals of the State of Israel and 'Israeli nationality' to the constituent Jewish-Israeli, Arab-Israeli, DruzeIsraeli and Circissan-Israeli people within the Israeli State. ${ }^{56}$

\section{F $\quad$ Statelessness and Nationality}

Statelessness is the condition in which an individual has no formal, legal or protective relationship with any recognised state, no matter their emotional national identification. In order words, statelessness is a condition where an individual has no nationality. It can also describe the situation where an individual claims the nationality of a 'State', but that 'State' is not internationally recognised. Statelessness can also be a situation where a person has lost their nationality for security reasons or other grounds associated with fraud. Finally, it can be a situation involving deprivation of nationality through the discriminatory laws of a state, resulting in lack of 'effective nationality' due to structural and administrative causes.

The concept of statelessness is enshrined in the 1954 Convention relating to the Status of Stateless Persons, whose art 1(1) defines a stateless individual as 'a person who is not considered as a national by any State under the operation of its

53 The Right to Nationality in Africa (Report, African Commission on Human and Peoples' Rights 2015) 13.

54 ibid.

55 'OHCHR and the Right to a Nationality', United Nations Office of the High Commissioner for Human Rights (Web Page) <https://www.ohchr.org/EN/Issues/Pages/Nationality.aspx>

56 See Jay Ruderman and Yedidia Z Stern, 'Is "Israeli" a Nationality', Israeli Democracy Institute (Blog Post, 9 March 2014) <https://en.idi.org.il/articles/6516>. 
law. ${ }^{57}$ With the rise of collective rights around the world, particularly in Africa, such a definition is outmoded for communities, groups and people. Within international organisations and the academia, there is a growing discourse on 'group Statelessness', 'Stateless minorities', and 'Stateless nations'. In fact, several studies have shown that three quarters of stateless persons in the world belong to minority groups. ${ }^{58}$ It is, however, important to know that the use of these concepts have been changing with time within the African human rights system. In the 1970s and 1980s, the use of peoples' rights was fashionable because of the clamour for independence. In 2020, with virtually almost all African states having attained their independence from foreign colonial rule, the concept of peoples' right to self-determination in human rights circles is decreasing, especially because its strong political connotation could become a source of secession of minority groups within most African countries. 59 The term 'community' is now frequently used in African legal and human rights institutions and current African case law as it is more neutral and credible than 'people'. ${ }^{60}$

The Constitution of the Federal Democratic Republic of Ethiopia is an African legal instrument that has long been able to make these concepts workable. Article 8 of the Constitution vests soverign powers on the Ethiopian nations, nationalities and people, while art 39 guarantees the right of self-determination to all Ethiopian nations, nationalities and people, including the right to secession. More importantly, the Ethiopian Constitution consecrates the right to nationality in art 33 and that of the nationality of children at birth in art 36(b). ${ }^{61}$ Beyond these definitions of terms and concepts, collective rights as related to nationality are better understood through a number of legal and sociological theories.

\section{The Theoretical Foundation of Collective Nationality Rights}

Central to understanding the relationship between collective rights and the right to nationality have been theories such as the recognition theory, the communitarian theory and the Ubuntu theory. The theory of recognition has been used in explaining the mass deprivation of nationality rights of migrants, women, minority, and indigenous groups the world over. In essence, the theory holds that formal and informal forms of recognition are fundamental in individual and group identification, the sense of belonging and perception of the right to nationality. Charles Taylor argues that there is a direct correlation between recognition and nationality, because nationality is largely shaped by recognition and misrecognition by others, or even institutions and governments. ${ }^{62} \mathrm{He}$ notes that misrecognition has an adverse impact on an individual or community's identity

57 Convention Relating to the Status of Stateless Persons, opened for signature 28 July 1951, 189 UNTS 150 (entered into force 22 April 1954).

58 See 'This Is Our Home': Stateless Minorities and Their Search for Citizenship (Report, UNHCR November 2017) 1 ('This Is Our Home Report').

59 See Redie Bereketeab, Self-Determination and Secession: A $21^{\text {st }}$ Century Challenge to the Post-Colonial State in Africa (Policy Notes No 5, The Nord Africa Institute 2012).

60 For several years now, cases brought before the Commission have been addressed under the banner of communities rather than people. Also, the 2003 Report of the African Commission's Working Group of Experts on Indigenous Populations/Communities also solidifies the use of the term 'communities': Report of the African Commission's Working Group of Experts on Indigenous Populations/Communities (Report, African Commission on Human and Peoples' Rights 2005).

61 See more at the Constitution of the Federal Democratic Republic of Ethiopia.

62 See Charles Taylor, 'The Politics of Recognition' in Amy Gutman (ed), Multiculturalism: Examining the Politics of Recognition (Princeton University Press 1994) 23, 37-42. 
and causes psychological harm, which is evident in victims of discrimination, racism, colonialism and arbitrary deprivation of nationality. ${ }^{63}$ This characterisation is visible in many African states where issues of statelessness or risk of statelessness occur. In addition, Axel Honneth views recognition as divisible into different dimensions, including respect, as individual equality, and esteem, as group solidarity. Through this lens, recognition is necessary to distributive justice in relation to rights, which individuals and groups are entitled to as equal nationals. Therefore, he perceives the entitlement and struggles for recognition as a competition for rights based on common and shared values with a given group. ${ }^{64}$

Communitarism describes some form of coming together as a community and portraying virtues of togetherness and communual existence as opposed to individuality and individual existence. The communitarian theory of citizenship, which is relevant to Africa where communal or communitarian values and rights precede individual values and rights, is also useful in understanding the dynamics of collective rights in the continent. These communtarian perspectives are safeguarded in Chapter II of the Banjul Charter particularly in arts 27 (2), 29(7) and 29(8). According to Munamato Chemhuru, if individuals preserve, respect, and strengthen African cultural values in a way that positively influences African communal and peoples' rights, then individual rights will be guaranteed. ${ }^{65}$

Srinvasa Myneni notes that communitarianism emphasises the connection between the individual and their community, which may be a family unit, but can also be a wider geographical location, or shared history. ${ }^{66} \mathrm{He}$ argues that communitarians see themselves as people born with identities such as male, female, working class, Black, Jewish or Muslim, and these identities place them within certain networks of social relations, because, in reality, not all individuals hold the liberal views of individualism. ${ }^{67}$ Most communitarians hold that in order for social harmony to prevail, individual rights and political liberties must be curtailed. Amitai Etzioni has further reinforced the communitarian perspective of citizenship, stating that all citizens will embrace core values for purposes of unity, but will follow their own subcultures in other matters for purposes of diversity. ${ }^{68}$ However, he cautions that Diversity Within Unity ('DWU') should be differentiated from radical multiculturalism, arguing that DWU should not be confused with 'unity in diversity', which is a popular political slogan. ${ }^{69}$

Finally, the indigenous African solidarity and communitarian concept of Ubuntu, is very relevant in understanding the collective right to nationality of a people or community in Afruca. In effect, Ubuntu is a Zulu word, which means humanness. It is derived from the ethical maxim, umuntu ngumuntu ngabantu, which means, 'a person is a person through other persons'. It means personhood

63 ibid.

64 See Axel Honneth, The Struggle for Recognition: The Moral Grammar of Social Conflicts (tr Joel Anderson, MIT Press 1992).

65 See Munamato Chemhuru, ‘African Communitarianism and Human Rights' (2018) 65(157) Theoria 37.

66 See Srinvasa Myneni, Citizenship and Emigration Law (Asia Law House 2013) (copy on hand with the author).

67 ibid 244.

68 Amitai Etzioni, 'Citizenship in a Communitarian Perspective' (2011) 11(3) Ethnicities 336.

69 ibid 341. 
and its rights could only be achieved through the values of solidarity, respect, and compassion for others. ${ }^{70}$

There have been different interpretations to Ubuntu, ranging from the official legal and policy positions to those which are highly personal, and scholarly interpretations. Dirk Louw, for instance holds that Ubuntu serves as the spiritual foundation of many African communities and cultures. ${ }^{71}$ John Hailey, on the other hand, argues that Ubuntu is not just a philosophical construct but also a practical demonstration of the core values of the African communal life. ${ }^{72} \mathrm{He}$ posits that Ubuntu has a role in valorising individual identity within the community. It promotes community building and collective work. It also promotes traditional conflict management through consensus-building and mediation, and it supports organisational management and effectiveness. ${ }^{73}$

Jacob Mugumbate and Andrew Nyanguru argue that Ubuntu could mean sympathy, compassion, benevolence, solidarity, hospitality, generosity, sharing, openness, affirming, available, kindness, caring, harmony, interdependence, obedience, collectivity and consensus. ${ }^{74}$ The African concept of Ubuntu is significant to this study because it focuses on the rights of the community over those of the individual. It implies for instance, that when a community is deprived of its rights to nationality, the individual of that community cannot enjoy such a right to nationality. As stated by Ingange-wa-Ingange:

The African human rights system forcefully took up the adage 'I am because we are' and argued that it was meaningless in the African context to adopt the notion of the autonomised individual divorced from his or her social community. ${ }^{75}$

\section{Manifestation Of Collective Peoples’ Rights in African Case LaW}

The decisions by the various human rights' interpretative bodies in the continent such as the African Commission on Human and Peoples Rights, the Committee of the African Charter for the Rights and Welfare of the Child and the African Court of Justice have led to an emergence of a distinct African case law on peoples' and community rights. The Commission's position on peoples' rights with regard to self-determination enshrined in art 20 of the Charter has been evolving over time and according to specific cases. In 1981, when the Charter was adopted, peoples' right to self-determination referred to African people under colonial and apartheid white-dominated regimes, especially those fighting peoples' liberation wars. The Commission made a conceptual shift in its definition of the rights of peoples to self-determination in its 1992 landmark Katangese Peoples' Congress v Zaïre

70 See more at Dirk J Louw, 'Ubuntu: An African Assessment of the Religious Other' (Conference Paper, 20th World Congress of Philosophy 1998) $<$ https://www.bu.edu/wcp/Papers/Afri/AfriLouw.htm>

71 ibid.

72 John Hailey, 'Ubuntu: A Literature Review' (Research Paper, The Tutu Foundation 2008) 7 $<$ https://web.archive.org/web/20150319084943/http://www.tutufoundationuk.org:80/docum ents/UbuntuLiteratureReview_JH_Dec08.pdf $>$.

73 ibid 13-18.

74 Jacob Mugumbate and Andrew Nyanguru, 'Exploring African Philosophy: The Value of Ubuntu in Social Work' (2013) 3(1) African Journal of Social Work 82, 85.

75 Ingange-wa-Ingange (n 13) 220. 
case ${ }^{76}$ In this decision, although the Commission did not rule in favour of the people of Katanga, it identified a number of variants to self-determination: be it that of external self-determination or internal self-determination. It then held that the Katangese people should exercise a variant of self-determination that is compatible with the sovereignty and territorial integrity of Zaire. ${ }^{77}$

The Commission's position was, however, different with the 1997 Casamance case, as it did not clearly explain the defining features of 'peoplehood' and whether the people of Casamance possess them before rejecting the claim of the Casamance separatists as a people. ${ }^{78}$ This was, however, not the case with Gunme and the SCNC v Cameroon in May 2009, where the Commission defined the features of 'peoplehood' in line with the 1989 definition of the UNESCO Committee of Experts and decided that:

'the people of Southern Cameroon' qualify to be referred to as a 'people' because they manifest numerous characteristics and affinities, which include a common history, linguistic tradition, territorial connection, and political outlook. More importantly they identify themselves as a people with a separate and distinct identity... It is up to other external people to recognise such existence, but not to deny it. ${ }^{79}$

The Commission's decision in the aforementioned case is in line with the theory of recognition, whereby communities with distinct identities must be recognised by the state as a people to have a sense of belonging.

Moreover, art 20(1) on the peoples' right to existence is a condition sine qua non for the right to self-determination and all other peoples' rights enshrined in the Charter. ${ }^{80}$ It is the mother of all peoples' rights as it confers upon individuals and people a 'legal status' enshrined in art 5 of the Charter. ${ }^{81}$ Ingange-wa-Ingange argues that the right to existence could be applied to ethnic groups within states whose specific physical or socio-cultural existence have to be protected. ${ }^{82}$ In the Jawara case, the Commission interpreted the peoples' right to existence to include the ability to exercise their political rights to freely choose their own governments and leaders, arguing that the 1994 coup against President Jawara was 'a violation of of the Gambian peoples' right to freely choose their government entrenched in art 20(1) of the Charter'. ${ }^{83}$

The Commission also consecrated the right of people to economic, social and cultural development, enshrined in art 22 in the 2003 Endorois Community $v$

76 See more at Decisions on Communications: 75/92 Congrès du peuple katangais/ Democratic Republic of the Congo (African Commission on Human and Peoples' Rights, $16^{\text {th }}$ ord sess, 2 March 1995) <https://www.achpr.org/sessions/view?id=63>.

77 ibid [4]-[6].

$7810^{\text {th }}$ Activity Report of the African Commission on Human and Peoples' Rights 1996/97 (Report, African Commission on Human and Peoples' Rights 1997) $<$ https://www.achpr.org/activityreports/viewall?id=10>.

79 Decisions on Communications: 266/03 Kevin Mgwanga Gunme et al / Cameroon (African Commission on Human and Peoples' Rights, 45 $5^{\text {th }}$ ord sess, 27 May 2009) $<$ https://www.achpr.org/sessions/descions?id=189>.

80 Ingange-wa-Ingange (n 13) 140.

81 Banjul Charter (n 24) art 5:

Every individual shall have the right to the respect of the dignity inherent in a human being and to the recognition of his legal status. All forms of exploitation and degradation of man particularly slavery, slave trade, torture, cruel, inhuman, or degrading punishment and treatment shall be prohibited.

82 See Ingange-wa-Ingange, (n 13) 140.

83 ibid 224; Jawara v Gambia (African Commission on Human and Peoples' Rights, Comms $147 / 95,149 / 96,27^{\text {th }}$ ord sess, 11 May 2000) [65]-[72]. 
Kenya ('Endorois') case, as it found the Government of Kenya guilty of evicting the Endorois people from their land to create a wildlife park. ${ }^{84}$ The Commission has also consecrated the right of a people to dispose freely of wealth and natural resources as enshrined in art 21 of the Charter in the 2001 SERAC (on Behalf of) the Ogoni People v Nigeria case, in which the Commission decided that 'with regard to a collective group, the resources belonging to it should be respected, as it has to use the same resources to satisfy its needs' ${ }^{85}$ More importantly, the Commission also used the SERAC (on Behalf of) the Ogoni People v Nigeria case to consecrate art 24 of the Charter related to the right of a people to a satisfactory environment. ${ }^{86}$

Apart from the African human rights system, other regional human rights systems have enshrined the promotion and protection of collective rights and have been developing a case law in that regard ${ }^{87}$ For instance, in 2006, the InterAmerican Court consecrated the peoples' collective right to property enshrined in the art 21 of the American Convention on Human Rights in the Sawhoyamaxa Indigenous Community v Paraguay case. ${ }^{88}$

\section{Peoples’ Rights, Nationality Rights and the Prevention of}

\section{STATELESSNESS IN AFRICA}

The rationale for a correlation between the collective rights of people and communities on the one hand, and promoting the right to nationality with the view of eradicating statelessness in Africa on the other cannot be understated. This right, which can apply to both individuals and recognised groups, people and communities, can play an important role in the eradication of statelessness. In effect, collective peoples' rights as embedded in art 1 of the ICESCR, art 27 of the ICCPR and arts 19-24 of the 1981 Banjul Charter provide a complementary framework to understand statelessness in Africa. The peoples' rights perspective is significant in the African context because of mass deprivations of citizenship rights through structural discrimination, exclusion and mass expulsions usually target groups collectively. The right to nationality is, therefore, not only an individual right, but also a collective right of communities, minority groups or people.

84 See Centre for Minority Rights Development and Minority Rights Group International and Centre on Housing and Evictions (Intervening) (On Behalf of the Endorois Welfare Council) $v$ Kenya, Communication No 276/2003, 46 ${ }^{\text {th }}$ ord sess (11-25 November 2009).

85 See Ingange-wa-Ingange (n 13) 214; Social and Economic Rights Action Centre (SERAC) and the Centre for Economic and Social Rights $v$ Nigeria (African Human Rights Commission, Comm No 155/96, 30 ${ }^{\text {th }}$ ord sess, (27 May 2002) [45].

86 Social and Economic Rights Action Centre (SERAC) and the Centre for Economic and Social Rights v Nigeria (n 85) [50]-[53].

87 Though it is important to note that the issue of peoples' rights, indigenous rights, in particular, have also been advanced in the Americas. The Inter-American system, through the InterAmerican Commission and Court, has equally undertaken a few decisions guaranteeing the protection of indigenous people and collective rights in the region. For instance, the 2001 case of Mayagna (Sumo) Awas Tingni Community v Nicaragua (Judgment) (Inter-American Court of America, Series C No 79, 31 August 2001) and the 2006 case of Sawhoyamaxa Indigenous Community v Paraguay (Judgment) (Inter-American Court of America, Series C No 146, 29 March 2006). It is also worth noting that in 2016, the Organization of American States adopted the American Declaration on the Rights of the Indigenous Peoples, AG/RES.2888 (XLVI$\mathrm{O} / 16$ ) (signed and entered into force 15 June 2016).

88 See Michael Talbot, 'Collective Rights in the Inter-American and African Human Rights Systems’ (2018) 49(1) Georgetown Journal of International Law 163, 169-70. 
In recent years, 'stateless communities', 'stateless people' and 'stateless nations' have been increasingly mentioned. ${ }^{89}$ In fact, the term 'stateless nation' was coined in 1983 by French political scientist Jacques Leruez in his book l'Ecosse, une nation sans etat, regarding the special status of Scotland in the United Kingdom. ${ }^{90}$ Since then, the term has been taken to describe an ethnic group, people or nation that does not possess its own state and is not the majority population in any nation-state. Members of stateless nations may be citizens of a country or countries and may be denied citizenship by countries they live in. ${ }^{91}$ The legal status given to most collectively refer to them simply as 'stateless minorities'. ${ }^{92}$ The literature on statelessness in Africa has varied from one region to another and has been marked by historical and political factors such as colonialism and state succession, historic migration, conflicts and forced displacement, elimination of political rivals, ethnic nationalism and regional integration.

Between 1960 and the 1990s, most of the statelessness-related research on the continent was centred on nationality laws. Recently, some comprehensive research on nationality and citizenship laws was done by Bronwen Manby, who showed the colonial influences on the national laws of most African countries. ${ }^{93}$ With regard to nationality rights, Manby has argued that the international regulation of nationality was historically organised for the benefit of states, rather than of people. ${ }^{94}$ In general, African nationality laws are based on jus sanguinis and jus soli. ${ }^{95}$ However, besides these two principles based on birth, two other factors influence the determination of nationality for adults: marriage to a citizen and long-term residence in a country. ${ }^{96}$ There is a similar risk of statelessness concerning ethnic or religious and linguistic minorities who are considered 'nonindigenous' to a country and have historical or cultural ties elsewhere. ${ }^{97}$ At the time of independence and the creation of new states in the continent, there were many residual 'transplanted' or historic migrant populations, who are now at risk of statelessness, because they were excluded from having the nationality of the new states. Prominent among them are the Asians, Arabs, Nubians and Somali in Kenya; the Lebanese in Sierra Leone; the Banyarwanda in the Democratic Republic of Congo and Uganda; and the Karana of Madagascar; to name a few. ${ }^{98}$

The problem with the current human rights-based research on nationality and statelessness is that it is mostly limited to the rights of individuals and persons. The human rights perspective to has been criticised by Hannah Arendt for its overreliance on the hegemonic nation-state international system, based on state rights.

89 See Minahan 'Encyclopedia of Stateless Nations, Ethnic and National Groups around the World' (n 39); Julius Friend, Stateless Nation: Western European Regional Nationalism and Old Nations (Palgrave 2012).

90 Jacques Leruez, l'Ecosse, une nation sans etat (Presses universitaires de Lille 1983).

91 Minahan, 'Encyclopedia of Stateless Nations, Ethnic and National Groups around the World' (n 39) xvii.

92 See This Is Our Home Report (n 58).

93 Bronwen Manby, Citizenship in Africa: The Law of Belonging (Hart Publishers 2018) 39-41.

94 ibid 23.

95 See, eg, Member State Expert Meeting on the Draft Protocol on the African Charter of Human and Peoples Rights on the Specific Aspects on the Right to a Nationality and the Eradication of Statelessness in Africa (Concept Note, African Union Commission, Department of Political Affairs 7-11 May 2018) 1.

96 ibid

97 Katherine Southwick and M Lynch, Nationality Rights for All: A Progress Report and Global Survey on Statelessness (Report, Refugees International 2009) 28.

98 See This Is Our Home Report (n 58). 
She argued that the decline of the nation-state in international relations has created new forms of social contracts and sense of belonging at sub-national and supranational levels, which undermine nationality. 99 Barzoo Eliassi explains that statelessness is a product of the hegemonic international system based on sovereign nation-states, which have the right to grant rights to include and exclude groups of people who are not viewed as 'core' members of the nation. ${ }^{100}$ The authority given to states by the international system to exclude persons or communities from belonging has led to discriminatory nationality laws and a high risk of group statelessness in Africa.

The African Union's perspective on the right to nationality became clearer when the African Commission on Human and Peoples' Rights ('ACHPR') requested its Special Rapporteur on Refugees, Asylum Seekers, Migrants, and Internally Displaced Persons in Africa in its Resolution 234 of April 2013 to carry out an in-depth study on the right to nationality in Africa. This was later followed by Resolution 277 of the 55 $55^{\text {th }}$ Ordinary Session of April-May 2014, where the ACHPR adopted the Study of its Rapporteur, The Right to a Nationality in Africa, which changed the narrative on the protection of stateless persons on the continent. It is against this background that a Draft Protocol to the Banjul Charter on the right to nationality and the eradication of statelessness, adopted in 2015 by the ACPHR and in July 2016 by the AU Kigali Summit, was subjected to the AU review process. ${ }^{101}$ On 17 October 2017, the Pan African Parliament also held a workshop on the right to nationality, which among other things, recommended that members should adopt the Draft Protocol of the African Charter on Human and Peoples' Rights on the Specific Aspects of the Right to a Nationality and the Eradication of Statelessness in Africa and include provisions on this right in their national legislation.

Between 2018 and 2020, the AU Commission organised meetings of experts to review the instrument in Johannesburg (South Africa) on 13-16 March 2018 and Abidjan (Cote D'Ivoire) on 7-11 May 2018. In February 2019, the Executive Council approved the draft Protocol and forwarded it to the Specialised Technical Committee on Justice and Legal Affairs for validation. Furthermore, during the High-Level Development Segment meeting ('HLS') of 7 October 2019 organised by UNHCR, the African Union Commission pledged that:

No later than the end of 2020, the African Union Commission commits to submit the draft Protocol to the African Charter on Human and Peoples' Rights on Specific Aspects of the Right to Nationality and Eradication of Statelessness in Africa for adoption by the AU Assembly. ${ }^{102}$

The clamour for an African solution to the problem of nationality and the eradication of statelessness has also been prevalent within the RECs, which are the building blocks of the AU human rights system. In North Africa, the countries of the AMU ascribe to the Arab Human Rights instruments, where the right to nationality is essentially an individual right and not a group or collective peoples'

99 See Hannah Arendt, The Origins of Totalitarianism (Harcourt, Brace \& Co 1951) 267-302.

100 Barzoo Eliassi, 'Statelessness in a World of Nation-States: The Cases of Kurdish Diasporas in Sweden and the UK' (2016) 42(9) Journal of Ethics and Migration Studies 1403.

101 See $40^{\text {th }}$ Report of the Activities of the African Commission on Human and People's Rights (African Union, Executive Council, Doc No EX.CL/968(XXIX), 15 July 2016).

102 See The World's Stateless: Deprivation of Nationality (Institute on Statelessness and Inclusion 2020) 44. 
rights. ${ }^{103}$ Since 2015 , other RECs have also taken initiatives to move the right to nationality and statelessness agenda within the frame of the Banjul Charter forward. ${ }^{104}$

An important development in the efforts to eradicate statelessness has been the establishment of national and regional statelessness determination procedures as advocated by UNHCR. In Europe, scholars such as Gábor Gyulai, Caia Vlieks and Katja Swider have described the establishment of such procedures in France, Georgia, Hungary, Italy, Latvia, Moldova, Spain, Turkey and the United Kingdom as commendable. ${ }^{105}$ Others, such as Noémi Radnai, have also been advocating for greater harmonisation of the procedures with the EU in line with the Meijers Committee for regional legal instruments and mechanisms, to ensure a standardised EU procedure on statelessness determination status. ${ }^{106}$ In Africa, the issue of statelessness determination procedures is also becoming fertile ground for researchers such as Raymond Atuguba, Francis Tuoukou and Vitus Gbang as well as Solomon Oseghale Momoh, Hanneke van Eijken and Cedric Ryngaet. 107 While launching the new African Humanitarian Policy Framework, the AU Commission promised to '[support] Member States in finding appropriate solutions for Stateless persons, including identification, documentation and other necessary assistance'. 108

103 See Zahra Albarazi, Regional Report on Citizenship: The Middle East and North Africa (Global Citizenship Observatory November 2017) 10.

104 These include the 2015 Abidjan Declaration on the Eradication of Statelessness (signed and entered into force 25 February 2015) by the Economic Community of West African States, the 2016 Resolution on the Prevention of Statelessness and the Protection of Stateless Persons in the SADC Region, SADCPF40-Res 001/16 (signed and entered into force 15 November 2016) by the SADC Parliamentary Forum, the 2017 Declaration of International Conference on the Great Lakes Region ('ICGLR') Member States on the Eradication of Statelessness, the 2018 N'Djamena Initiative on the Eradication of Statelessness in Central Africa, CIRGL/CIMR/DEC/15/10/2017 (signed and entered into force 16 October 2017), just to name a few.

105 Gábor Gyulai, 'The Determination of Statelessness and the Establishment of a StatelessSpecific Protection Regime' in Laura van Waas and Alice Edwards (eds), Nationality and Statelessness under International Law (Cambridge University Press 2014); Caia Vlieks 'Strategic Litigation: An Obligation for Statelessness Determination under the European Convention on Human Rights?' (Discussion Paper No 09/14, European Network on Statelessness 2014); Katja Swider, 'Protection and Identification of Stateless Persons Through EU Law' (Working Paper Series, Amsterdam Centre for European Law and Governance 2014).

106 See Noémi Radnai, 'Statelessness Determination in Europe: Towards the Implementation of Regionally Harmonised National Statelessness Determination Procedures' (Statelessness Working Paper Series No 2017/08, Institute on Statelessness and Inclusion 2018); Noémi Radnai, 'Harmonising Standards on Statelessness Determination in Europe', European Network on Statelessness Blog (Blog Post, 1 March 2018) $<$ https://www.statelessness.eu/updates/blog/harmonising-standards-statelessnessdetermination-europe>; Meijers Committee, 'A Proposal for an EU Directive on the Identification of Statelessness and the Protection of Stateless Persons' (13 October 2014) $<$ https://www.statewatch.org/media/documents/news/2014/oct/eu-meijers-cttee-call-for-anEU-directive-on-the-identification-and-protection-of-stateles-persons.pdf $>$.

107 See Raymond A Atuguba, Francis Xavier Dery Tuokuo and Vitus Gbang, 'Statelessness in West Africa: An Assessment of Stateless Populations and Legal, Policy, and Administrative Frameworks in Ghana' (2020) 8(1) Journal of Migration and Human Security 14; Solomon Oseghale Momoh, Hanneke van Eijken and Cedric Ryngaet, 'Statelessness Determination Procedures: Towards a Bespoke Procedure for Nigeria' (2020) 2(1) Statelessness \& Citizenship Review 86.

108 African Union Commission, Department of Political Affairs: Humanitarian Affairs, Refugees and Displaced Persons Division, African Union Humanitarian Policy Framework (20 November 2015) 13 [56]. 
In September 2020, Cote d'Ivoire became the first African country to establish a statelessness determination procedure, ${ }^{109}$ although a dozen African countries had pledged to establish such procedures during the HLS in October 2019.110 Moreover, art 21 of the Draft Protocol stipulates that African states should take all necessary measures to establish all possible frameworks to guarantee the right to nationality.

\section{A Manifestation of Individual and Collective Right to Nationality in African}

\section{Case Law}

The Commission has used its interpretative mandate to contribute to the development of a specific African case law on the right to nationality and the prevention of statelessness in the continent. Because of the absence of a specific provision on this right to nationality, the Commission has been basing its arguments on several other individual, group, and peoples' rights to find redress to human rights abuses. In making advisory opinions on individual rights to nationality, the Commission has been basing its arguments on art 2 (principle of non-discrimination), art 5 (legal status) and art 12 of the Charter. There have been a number of cases in which the right to nationality, based on these articles, were brought before the Commission. ${ }^{111}$

This non-discriminatory principle can help significantly in addressing the discriminatory laws in the continent, which are contributory causes of statelessness in Africa. In this connection, the Draft Protocol has integrated the non-discrimination principle, where it stipulates that:

The rules and practices of a State Party on nationality shall not contain distinctions or include any exclusion, or restriction or any different treatment based on grounds

109 See more at 'Côte d'Ivoire Adopts Africa's First Legal Process to Identify and Protect Stateless People', UNHCR (4 September $<$ https://www.unhcr.org/news/press/2020/9/5f51f33b4/cote-divoire-adopts-africas-firstlegal-process-identify-protect-stateless.html>.

110 'Results of the High-Level Segment on Statelessness', United Nations High Commissioner for Refugees (Web Page, October 2019) < https://www.unhcr.org/ibelong/results-of-the-highlevel-segment-on-statelessness/>.

111 Cases related to citizenship include: John K Modise v Botswana (African Commission of Human and Peoples' Rights, Comm 97/93, 28 th ord sess, 6 November 2000) ('John K Modise $v$ Botswana'); Amnesty International v Zambia (African Commission of Human and Peoples' Rights, Comm 212/98, $25^{\text {th }}$ ord sess, 5 May 1999) ('Amnesty International v Zambia'); Union Interafricaine des Droits de l'Homme v Angola (African Commission on Human and Peoples' Rights, Comm 159/96, 22 nd ord sess, 11 November 1997) ('Union Interafricaine des Droits de l'Homme v Angola'); Organisation Mondiale Contre la Torture v Rwanda (African Commission on Human and Peoples' Rights, Comms 27/89, 49/91 and 99/93) ('Organisation Mondiale Contre la Torture v Rwanda'); Rencontre Africain pour la Défense des Droits de l'Homme v Zambia (African Commission on Human and Peoples' Rights, Comm 71/92, $20^{\text {th }}$ ord sess, October 1997) ('Rencontre Africain pour la Défense des Droits de l'Homme v Zambia'); Legal Resources Foundation v Zambia (n 47); Institute for Human Rights and Development in Africa v Angola (African Commission on Human and Peoples' Rights, Comm 292/2004, 43 ${ }^{\text {rd }}$ ord sess, 22 May 2008) ('Institute for Human Rights and Development in Africa v Angola'); Institute for Human Rights and Development in Africa (on Behalf of Sierra Leonean Refugees in Guinea) v Republic of Guinea (African Commission on Human and Peoples' Rights, Comm 249/02, 36 $6^{\text {th }}$ ord sess, 7 December 2004) ('Institute for Human Rights and Development in Africa (on Behalf of Sierra Leonean Refugees in Guinea) v Republic of Guinea'); Mouvement ivoirien des droits humains (MIDH) v Côte d'Ivoire (African Commission on Human and Peoples' Rights, Comm 246/02, $5^{\text {th }}$ extraordinary sess, 29 July 2008). 
of race, ethnic group, colour, sex, language, religion, political or any other opinion, national or social origin, fortune, disability, birth, or other status... 112

On the other hand, the principle of legal status engrained in art 5 of the Banjul Charter states that '[e]very individual shall have the right to the respect of the dignity inherent in a human being and to the recognition of his legal status' has developed into an African legal doctrine on nationality. ${ }^{113}$ During its $53^{\text {rd }}$ Session in April 2013, for instance, the Commission consecrated this principle of legal status, which has been substantiated by case law in adopting Resolution 234, which states that:

$[T]$ he right to nationality of every human person is a fundamental human right implied within the provisions of Article 5 of the African Charter for Human and People's Rights and essential to the enjoyment of other fundamental rights and freedoms under the Charter. ${ }^{114}$

The Legal Status doctrine on the right to nationality has also found expression in the idea of a common legal identity, which is Goal 16 of the Sustainable Development Goals ('SDGS') and has been a major focus of the SADC countries. In August 2016, the SADC Migration Dialogue for Southern Africa ('MIDSA') in Gaborone promised to work towards a SADC Ministerial Declaration on the Right to Nationality and Statelessness. ${ }^{115}$ Moreover, in November 2016, the SADC Parliamentary Forum adopted a resolution on 'the Prevention of Statelessness and the Protection of Stateless Persons in the SADC Region', based on the promotion of a common legal identity by 2030 in accordance with Goal 16 of the Sustainable Development Goals. ${ }^{116}$

The case law of the Commission has also used art 5 on legal status to consecrate the right to nationality, not only to individuals, but also to people and communities. In the 1998 Legal Resources Foundation v Zambia case, the Commission stated that the application of the term 'peoples' to a section of the population of a state or the concept of 'peoplehood' to any group of persons must include persons who are bound together by reason of common ancestry, ethnic origin, language or cultural habits. ${ }^{117}$ Frans Viljoen concludes that ' $[\mathrm{b}] \mathrm{y}$ adopting this approach, at least in that particular instance, the Commission gives a clear indication that a linguistic or ethnic sub-set of the population may qualify as a "people". ${ }^{118}$ Although this provision refers to individual rights, its reference to race and ethnic group also makes it a potential collective right to address the problem of mass expulsions. ${ }^{119}$

112 See Draft Protocol to the African Charter (n 10) art 4(1).

113 See generally John K Modise v Botswana (n 111).

114 See African Commission on Human and Peoples' Rights, Resolution on the Right to Nationality, Doc No ACHPR/Res.234 (LIII) 13, 53 ${ }^{\text {rd }}$ ord sess, 23 April 2013 $<$ https://www.achpr.org/sessions/resolutions?id=260>. This position had already been taken in: John K Modise v Botswana (n 111) [91]; Amnesty International v Zambia (n 111) [50].

115 See Liesl H Muller, 'Legal Identity for All - Ending Statelessness in SADC' in Goal 16 of the Sustainable Development Goals: Perspectives from Judges and Lawyers in Southern Africa on Promoting Rule of Law and Equal Access to Justice (Southern African Litigation Centre 2016) 140, 143.

116 ibid 142.

117 Legal Resources Foundation v Zambia (n 47) [73].

118 See Frans Viljeon, International Human Rights Law in Africa (Oxford University Press 2007) 223.

119 See generally Tamás Molnár, 'The Prohibition of Arbitrary Deprivation of Nationality under International Law and EU Law: New Perspectives' [2014] Hungarian Yearbook of International Law and European Law 67. 
In the 2015 Nubian Community in Kenya $v$ the Republic of Kenya case, the Commission found that the collective complaint of the 'Nubian Community' was admissible through as assessment of merits. It focused on the rights of individuals in the community to a nationality and stated that:

$[\mathrm{N}]$ ationality is intricately linked to an individual's juridical personality and that denial of access to identity documents which entitles an individual to enjoy rights associated with citizenship violates an individual's right to the recognition of his juridical personality. The Commission considers that a claim to citizenship or nationality as a legal status is protected under Article 5 of the Charter. ${ }^{120}$

The Commission therefore held that Kenyan Nubians were arbitrarily deprived of the effective enjoyment of their nationality, making many of them essentially stateless. ${ }^{121}$ In another 2015 landmark merits opinion, Open Society Justice Initiative (OSJI) $v$ Cote d'Ivoire, the Commission ruled that the Ivoirian Government violated art 5 of the Banjul Charter to members of the cross-border 'Dioula Ethnic Group', split between Cote d'Ivoire and Burkina Faso, by depriving them of the right to nationality. ${ }^{122}$ The Commission has also decided on mass deportation and expulsion in the continent based on individual rights in arts 2, 7, 12 and 14 of the Charter to find redress in cases of mass expulsions by Rwanda, Zambia, Angola and Guinea. ${ }^{123}$

In the 1996 Union Inter-Africaine $v$ Angola case, related to the mass expulsion of West African citizens by the Government of Angola, the Commission ruled that:

Mass expulsions of any category of persons, whether on the basis of nationality, religion, ethnic, racial or other considerations, constitute a special violation of human rights. ${ }^{124}$

The right to property in art 14 of the Charter was also used in the 1989 Malawi African Association v Mauritania case in which thousands of black Mauritanians were collectively deprived of their nationalities and properties then expelled to Senegal. The Commission concluded that:

The confiscation and looting of the property of black Mauritanians and the expropriation or destruction of their land and houses before forcing them to go abroad constitute a violation of the right to property as guaranteed in Article 14. ${ }^{25}$

In December 2004, the Commission further condemned the mass expulsion of Sierra Leoneans by the Government of Guinea as a violation of human rights in Sierra Leone Refugees $v$ the Republic of Guinea case. ${ }^{126}$

120 The Nubian Community in Kenya $v$ The Republic of Kenya (African Commission on Human and Peoples' Rights, Comm 317/ 06, $17^{\text {th }}$ extraordinary sess, 19 -28 February 2015) 28-29.

121 ibid 29 [142].

122 Open Society Justice Initiative v Côte d'Ivoire (African Commission on Human and Peoples' Rights, Comm 318/06, 28 February 2015) 11-12 [47]-[48].

123 Organisation Mondiale Contre La Torture v Rwanda (n 111); Amnesty International $v$ Zambia (n 111); Rencontre Africaine pour la Defense des Droits de l'Homme v Zambia (n 111); Union Inter-Africaine des Droits de l'Homme v Angola (n 111); Institute for Human Rights and Development in Africa (on Behalf of Sierra Leonean Refugees in Guinea) $v$ Republic of Guinea (n 111).

124 Union Inter-Africaine des Droits de l'Homme v Angola (n 111) [68].

125 Malawi African Association v Mauritania (African Commission on Human and Peoples' Rights, Comms 54/91, No 61/91, No 98/93, No 164/97, No 196/97, No 210/98, $27^{\text {th }}$ ord sess, 11 May 2000) [128].

126 See Institute for Human Rights and Development in Africa (on Behalf of Sierra Leonean Refugees in Guinea) v Guinea (n 111). 
Apart from the individual rights, the Commission has also been based its case law on nationality-related mass expulsions in Africa by invoking art 18 of the Charter, protecting the collective group rights of families. In the 1996 Amnesty International $v$ Zambia case, the Commission found Zambia guilty of forcible expulsion of the complainants and breaking up their families, which was in violation of arts 18(1) and 18(2) of the Charter. The Commission also condemned the Angolan Government in the Union Inter-Africaine des Droits de l'Homme $v$ Angola case for violating art 18 by deporting hundreds of West African migrants, and thereby separating their families. It maintained the same rationale in the Malawi African Association $v$ Mauritania case. At the level of the case law developed at the level of RECs, the East African Community ('EAC') Court of Justice in 2016 condemned the failure of the EAC institutions to investigate and provide redress for the illegal expulsion of immigrants in Tanzania under its 'Operation Kimbunga' of 2003. ${ }^{127}$

Apart from the Commission, there is also a growing case law in Africa on the right to nationality and child statelessness by the African Committee of Experts on the Rights and Welfare of the Child ('ACERWC') based on violations of arts 3 and 6 of its Charter. In March 2011, for instance, the ACERWC passed a decision on the landmark IHRDA and OSJI on Behalf of Children of Nubian Descent in Kenya $v$ Kenya case, in which it held that it 'cannot overemphasize the overall negative impact of statelessness on children', stating that:

[A]s much as possible, children should have a nationality beginning from birth ... Moreover, by definition, a child is a person below the age of 18 (Article 2 of the African Children's Charter) and the practice of making children wait until they turn 18 years of age to apply to acquire a nationality cannot be seen as an effort on the part of the State Party to comply with its children's rights obligations. ${ }^{128}$

There was also the ACERWC decision of 2018 on the case of African Centre of Justice and Peace Studies (ACJPS) and Peoples' Legal Aid Centre (PLACE) v the Republic of Sudan, in which the Committee further elucidated the relationship between the right to a nationality as protected in arts 6 and 3 of the African Charter on the Rights and Welfare of the Child ${ }^{129}$ on non-discrimination, concluding that the applicant had been arbitrarily deprived of her Sudanese nationality. ${ }^{130}$

Since its inception, the African Court on Human and Peoples Rights has also been contributing to the development of a specific African case law on the right to nationality and the prevention of statelessness in the continent. On 22 March 2018, for instance, it handed its first judgment on a case related to the right to nationality

127 See East African Law Society v Secretary General of EAC (Reference No 7 of 2014) [2016] EACJ 113 (22 March 2016).

128 Institute for Human Rights and Development in Africa (IHRDA) and Open Society Justice Initiative (on Behalf of Children of Nubian Descent in Kenya) $v$ the Government of Kenya (African Committee of Experts on the Rights and Welfare of the Child, Decision No 002/Com/002/2009, 22 March 2011) 10 [46], 9 [42].

129 The African Charter on the Rights and Welfare of the Child is a regional human rights treaty that sets out rights and defines principles for the status of children on the continent: African Charter on the Rights and Welfare of the Child, adopted 11 July 1990, OAU Doc CAB/LEG/24.9/49 (entered into force 29 November 1999).

130 See African Committee of Experts on the Rights and Welfare of the Child, African Centre of Justice and Peace Studies (ACJPS) and Peoples' Legal Aid Centre (PLACE) v the Republic of Sudan (African Committee of Experts on the Rights and Welfare of the Child, Decision No $002 / 2018,31^{\text {st }}$ ord sess, 29 November 2018). 
and prevention of statelessness in the Anudo Ochieng Anudo v Tanzania case. ${ }^{131}$ Interestingly, the judgment did not rely on the precedents of the Commission that 'a claim to citizenship or nationality as a legal status is protected under art 5 of the Charter'. Instead, it relied on universal principles such as art 15 of the UDHR and art 13 of ICCPR to rule that states must prove that a complainant does not have citizenship. Among other things the Court stressed that:

[B]y declaring the Applicant an 'illegal immigrant' thereby denying him Tanzanian nationality, which he has, until then enjoyed, without the possibility of an appeal before a national court, the Respondent State violated his right to have his cause heard by a judge within the meaning of Article 7(1)(a), (b), and (c) of the ICCPR. 132

The Court further noted that the Tanzanian Citizenship Act contains gaps in as much as it does not allow citizens by birth to 'exercise judicial remedy where their nationality is challenged as required by international law'. ${ }^{133}$ It is the opinion of the Court that the respondent state has the obligation to fill the said gaps. The Anudo Ochieng Anudo v Tanzania case was also followed by that of Robert John Penessis $v$ United Republic of Tanzania, the latter being the second case decided by the Court that considers the right to a nationality. Here, the Court affirmed its commitment to protection of the right to a nationality as per art 15 of the $U D H R$, in line with the reasoning in Anudo. ${ }^{134}$ The Court drew on African Commission case law to state that the right to a nationality is implied within art 5 of the African Charter on the 'right to the respect of the dignity inherent in a human being and to the recognition of his legal status' and also affirmed views previously developed in its own decisions and those of the African Commission on the burden of proof in such cases. ${ }^{135}$

There have also been cases of collective right to nationality and risk of statelessness in Africa decided outside the continent. In December 1973, the European Court of Human Rights ruled in East African Asians $v$ the United Kingdom that the 1968 Commonwealth Immigrants Act of the UK Government was discriminatory and deprived many East African Asians of their British nationality, which could result in statelessness. ${ }^{136}$ Similarly, mass deprivation of nationality and the risk of statelessness have also been addressed by the case law of other regional human rights bodies such as the Inter-American Court. In September 2013, for instance, the Supreme Court of Dominican Republic stripped some 200,000 persons of Haitian descent of their Dominican nationality. ${ }^{137}$ This led to the 2014 Case of Expelled Dominicans and Haitians $v$ Dominican Republic, where the Inter-American Court explained that when regulating the granting of

131 Anudo Ochieng Anudo v Tanzania (Judgment) (African Court on Human and Peoples' Rights, App No.012/2015, 22 March 2018).

132 ibid [115].

133 ibid [116].

134 Robert John Penessis v United Republic of Tanzania (Judgement) (African Court on Human and Peoples' Rights, App No.013/2015, 28 November 2019 ('Penessis v Tanzania'); see also Bronwen Manby and Clement Bernardo Mubanga, 'Robert John Penessis $v$ United Republic of Tanzania (Judgement) (African Court on Human and Peoples’ Rights, App No.013/2015, 28 November 2019)' (2020) 2(1) Statelessness \& Citizenship Review 172.

135 Penessis $v$ Tanzania (n 134) [84].

136 See East African Asians v United Kingdom (1973) 3 EHHR 76.

137 See TC/0168/13, 23 September 2013 (Constitutional Court of the Dominican Republic). 
nationality, states must avoid rendering persons stateless and must not discriminate in the right to nationality. ${ }^{138}$

\section{CONCLUSION}

From the aforementioned discussions on current practice related to collective peoples' and community rights on the African continent, it is evident that the right to nationality in Africa can take place at different levels, namely the state, the community and the individual levels. This article has shown that a people or a community could collectively present a case for a right to nationality in Africa, because of the communitarian values of Ubuntu and the provisions of the Banjul Charter, which make collective rights a reality. The Banjul Charter has made provisions for many rights to be enjoyed as individual, group and collective peoples' rights and the 2001 SERAC (on Behalf of) the Ogoni People v Nigeria case has shown the indivisibility, interdependence and interrelatedness of individual, group and people's rights in the continent. The right to nationality is one of those cross-cutting rights that could be conferred by the state and enjoyed as an individual, group, people and community right. This study has shown that when nationality-related rights are violated, the Commission, Committee or Courts have resorted to individual, group and peoples' rights provisions of the Charter to address the violation and issue remedies.

However, the African interpretative bodies such as the Commission, the Committee and the Court have no real follow-up, implementation and enforceability mechanisms. There is also no legally prescribed consequence for a signatory's non-compliance with their recommendations. ${ }^{139}$ Consequently, African states have been slow and not very consistent in addressing and abiding by the decisions and recommendations from the Commission, Committee and Court. For instance, in Institute on Human Rights and Development and Open Society Justice Initiative $v$ Kenya ('Kenyan Nubian children case'), ${ }^{140}$ the affected children still face discrimination in birth registration, which puts them at risk of statelessness. ${ }^{141}$ In the Endorois case, the implementation by the Kenyan Government is equally slow in spite of the organisation of community workshops, strategic exchanges with community members and allies, the Government and the Commission. ${ }^{142}$ Moreover, given the fact that litigation is expensive and that many persons whose rights to nationality are being violated is because they belong to particular communities or people, future actions will be more constructive and in the interest of all if they target collective peoples' right to nationality.

The collective peoples' rights perspective to understanding statelessness in Africa is further grounded in the African communitarian system and belief in

138 See Case of Expelled Dominicans and Haitians $v$ Dominican Republic (Judgment) (Inter-American Court of Human Rights, Series C No 282, 28 August 2014) $<$ https://corteidh.or.cr/docs/casos/articulos/seriec_282_ing.pdf $>$.

139 See Morne van der Linde and Lirette Louw, "Considering the Interpretation and Implementation of Article 24 of the African Charter on Human and People's Rights in the Light of the SERAC Communication' (2003) 3(1) African Human Rights Law Journal 167. $<$ https://www.corteidh.or.cr/tablas/R21586.pdf $>$.

140 Institute on Human Rights and Development and Open Society Justice Initiative v Kenya (Kenyan Nubian children) (Judgement) (African Committee of Experts on the Rights and Welfare of the Child, Case No. 02/2010, 22 March 2011).

141 See Implementation of the Nubian Minors $v$ Kenya (Briefing Paper, African Committee of Experts on the Right and Welfare of the Child February 2014).

142 See 'The Endorois Case' ESCR-Net (Web Page, 5 June 2018) <https://www.escrnet.org/news/2018/endorois-case $>$. 
Ubuntu: that an individual is a person, only because they come from a community. Moreover, attempts to obtain individual citizenship for persons from discriminated groups have been difficult. Therefore, making the right to nationality a peoples' or community right will cover the rights of individuals who belong to the community. The study has shown the risk of statelessness resulting from the mass expulsions related to a collective deprivation of the right to nationality in the case of black Mauritanians. ${ }^{143}$ Furthermore, this article has also shown that statelessness has gone beyond its limited legalistic perspectives of 'stateless persons' to embrace the broader socio-political perspectives of 'stateless people' and 'stateless nations', where the right to nationality could best be enjoyed collectively as a people and community.

The elaboration of the AU's Protocol on the right to nationality is a major challenge because for the past 40 years most new African human rights instruments have deviated from the 1981 Banjul spirit. The spirit of compromise arrived at in Banjul in 1981 when elaborating a distinct African human rights system that will encompass both individual and solidarity collective peoples' rights has apparently been abandoned. In fact, most of them tend to discuss human rights in the continent purely in terms of the protection and promotion of the rights of persons and individuals. Although the political compromise of the Banjul Charter seems to sway towards individual rights, it is however, gratifying to observe the interpretative bodies of the Banjul-led African human rights system have not failed to generate and hand down a case law that reset the 1981 spirit of compromise on collective and individual rights in Africa. It is therefore important that in subsequent instruments there is still this notion of peoples' rights being highlighted as an African specificity.

This study has demonstrated that given the existing African case law on peoples' rights, and recent trends on statelessness, it might be important to include a collective peoples' rights perspective to the right to nationality as an effort to eradicate statelessness in the continent. It also serves as a wakeup call for African legal experts and human rights institutions to refocus on the fading Banjul spirit of peoples' rights when drafting and adjudicating on human rights issues in the continent to reflect its specificities and realities.

Since 2015, there have been efforts to develop the Draft Protocol to the African Charter on Human and Peoples' Rights on Certain Aspects of the Right to a Nationality and the Eradication of Statelessness in Africa, which still focuses on the perception that nationality is essentially an individual right. In fact, only art 8 related to the nomadic and cross-border communities recognises this collective right to nationality. With the Draft Protocol on Nationality, the AU has an opportunity to reset the compromise of making nationality rights a right that could be enjoyed in the continent by individuals, groups, people, and communities recognised by African states.

143 See 'Mauritania: Persecution of Black Mauritanians - Summary Execution, Deprivation of Citizenship, Illegal Expulsions, and Arbitrary Arrests', Human Rights Watch, News from Africa Watch (Mauritania, 7 September 1989). Other examples of mass expulsions in Africa have been in Nigeria 1960, 1983, 2006, Ghana 1965 and 1970, Zambia 1992 and Angola 1976. 